\title{
Imbalanced nutrients as triggers for black shale formation in a shallow shelf setting during the OAE 2 (Wunstorf, Germany)
}

\author{
M. Blumenberg ${ }^{1}$ and F. Wiese ${ }^{2}$ \\ ${ }^{1}$ Geobiology Group, Geoscience Centre, Georg-August-University Göttingen, Goldschmidtstr. 3, 37077 Göttingen, Germany \\ ${ }^{2}$ Courant Research Centre Geobiology, Georg-August-University Göttingen, Goldschmidtstr. 3, 37077 Göttingen, Germany
}

Correspondence to: M. Blumenberg (martin.blumenberg@geo.uni-goettingen.de)

Received: 19 April 2012 - Published in Biogeosciences Discuss.: 9 May 2012

Revised: 14 September 2012 - Accepted: 21 September 2012 - Published: 29 October 2012

\begin{abstract}
During the oceanic anoxic event 2 (OAE 2) in the Mid-Cretaceous Period, widespread black shale (BS) formation occurred, reflecting perturbations in major biogeochemical cycles. Here we present geochemical and biomarker data of the OAE 2 from a shelf setting situated at about 100$150 \mathrm{~m}$ water depth (Wunstorf, Germany). Our data support that processes inducing BS deposition were related to orbital cyclicity in Wunstorf and that they were not restricted to the time of the OAE 2 carbon isotope excursion. Correlations of total organic carbon (TOC) and $\delta^{15} \mathrm{~N}$ and high relative abundances of functionalized hopanoids (including 2-methylated structures) suggest that BS were formed during times of imbalanced nutrients with high phosphorus inputs and increased cyanobacterial nitrogen fixation. Periods of BS formation were also characterized by enhanced growth of dinoflagellates and bacteriovorous ciliates, the latter supporting the presence of a stratified water body. The lack of biomarkers specific for green sulfur bacteria excludes photic zone euxinia during OAE 2 in Wunstorf. Conflicting maturities and biomarker distributions in kerogen and extractable organic matter and, interestingly, a negative correlation of the diagenetically resistant 2-methyl hopane hydrocarbons with TOC indicate a complex depositional setting at Wunstorf. This might have been induced by high continental runoff during BS formation and the accompanying mobilisation of refractory $\mathrm{OM}$ from the shelves and near shore areas.
\end{abstract}

\section{Introduction}

In the Mid-Cretaceous Period, elevated concentrations of $\mathrm{CO}_{2}$ created a greenhouse world with elevated temperatures and reduced oceanic circulation. As a result, oceanic sediments recorded several organic-rich black shales (BS) during so-called Oceanic Anoxic Events (OAEs; Schlanger and Jenkyns, 1976). Two mechanisms or the combination of these processes were proposed as responsible for BS formation, enhanced bioproductivity and/or enhanced preservation of organic matter as a result of anoxic conditions (e.g., Arthur et al., 1988; Jenkyns, 2010; Mort et al., 2007). One of the best studied OAE occurred at the Cenomanian-Turonian boundary ( 93.5 Ma), and its global impact is evident from a positive carbon isotope excursion (CIE) in carbonate and total organic carbon (TOC), most likely reflecting increased carbon burial due to enhanced biological production (Jarvis et al., 2011, and references therein).

Numerous geochemical and biomarker studies on regional and global aspects of OAE 2 BS formation were published in the last decades. Stable carbon isotope ratios of chlorophyllderived phytane support that $p \mathrm{CO}_{2}$ was high during OAE 2 (Freeman and Hayes, 1992; van Bentum et al., 2012) with a $p \mathrm{CO}_{2}$ almost 5 times higher than modern values (maximizing at $1750 \mathrm{ppm})$. As a key aspect explaining the enhanced $p \mathrm{CO}_{2}$, massive $\mathrm{CO}_{2}$ emissions due to the eruption of the Caribbean Large Igneous Province (CLIP) were suggested (Sinton and Duncan, 1997; Turgeon and Creaser, 2008). Following these enhanced $\mathrm{CO}_{2}$ concentrations, an extensive greenhouse climate developed with surface ocean water temperatures of more than 30 to $35^{\circ} \mathrm{C}$ (calculations based on the TEX86 proxy; Forster et al., 2007; Sinninghe 


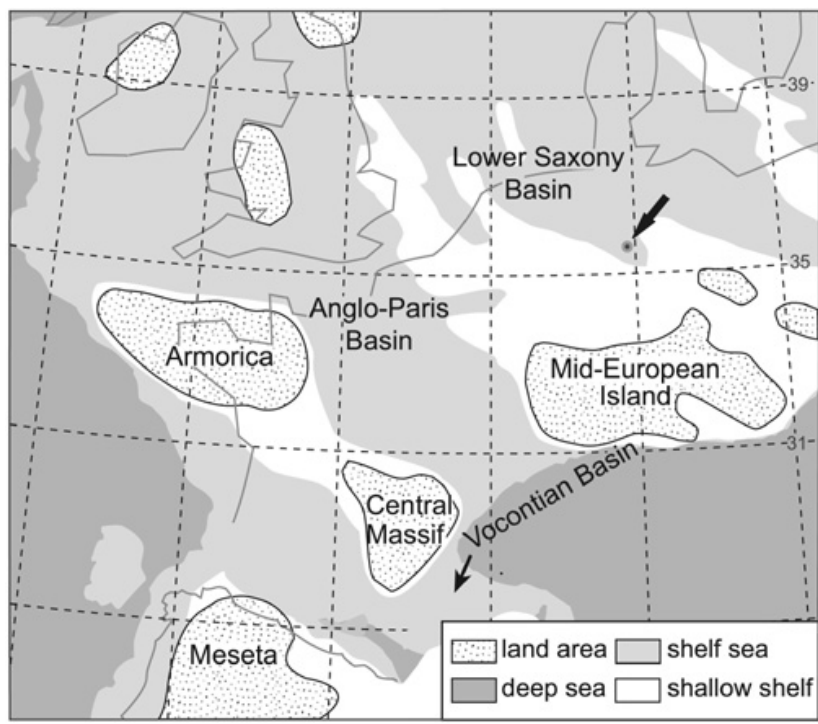

Fig. 1. Paleoceanographic situation at the Cenomanian-Turonian Boundary and the sampling site (Wunstorf; modified after Voigt et al. (2004). The working area is indicated by dot and arrow).

Damsté et al., 2010). Exciting findings of green sulfur bacteria biomarker indicate that local photic zone euxinia existed - suggesting stagnant or sluggish ventilated oceans with an extension of the oxygen minimum zone (OMZ) at least periodically into the photic zone (e.g., Pancost et al., 2004; Sinninghe Damsté and Köster, 1998). Moreover, nitrogenfixing cyanobacteria were recognized as key players during black shale formation (Kashiyama et al., 2008; Kuypers et al., 2002, 2004; Ohkouchi et al., 2006). A major argument for cyanobacterial nitrogen fixation as a process supporting primary production under low N/P conditions are high 2methyl hopane occurrences in the central North Atlantic during OAE 2 (Kuypers et al., 2004). However, in other OAE 2 settings, 2-methyl hopanoids were not found (in Livello Selli and Livello Bonarelli BS), although porphyrin nitrogen in the respective rocks was most likely also mainly sourced by cyanobacteria (Kashiyama et al., 2008). In a recent study, an elegant explanation for the ${ }^{15} \mathrm{~N}$-depleted biomass, and chlorophyll derivatives in particular, accompanied by the partial lack of cyanobacterial biomarkers was presented. Based on the study of nitrogen stable isotope ratios of porphyrins and on modeling approaches, it was suggested that a significant proportion (about $80 \%$ ) of the ${ }^{15} \mathrm{~N}$-depleted biomass has an algal and not cyanobacterial origin (Higgins et al., 2012). Higgins et al. (2012) suggested a nitrogen cycle in which ${ }^{15} \mathrm{~N}$-depleted biomass from diazotrophic cyanobacteria was mineralized to $\mathrm{NH}_{4}^{+}$in the anoxic bottom waters. Upwelling then brought this isotopically distinct ammonia $(\sim-1 \%$ ) to the surface, where it was preferentially consumed by algae and transferred with its bacterial signature into the sediments.
There exists a considerable number of contributions to open oceanic OAE 2 occurrences from ODP sites (e.g., Kuypers et al., 2004) and onshore occurrences (e.g., Tsikos et al., 2004), but there is no knowledge so far on microbial communities and their contribution to BS deposition in palaeo-shelf settings with comparatively moderate water depths. Here, we present biomarker data from the Wunstorf core (Lower Saxony, Germany), deposited at water depths around 100-150 m water depth (Wilmsen et al., 2005) on the central European shelf, possibly the shallowest OAE 2 BS recorded so far.

We concentrate in particular on functionalized lipids, as these biosignatures are less prone to allochthonous transport processes due to their lower diagenetic stability compared to the commonly reported suites of hydrocarbon biomarkers. Moreover, biomarkers covalently linked to the major pool of organic matter in sediments (kerogen) were analyzed in order to obtain data on organisms whose contributions to sediments is usually negatively biased when working solely on extractable biomarkers. The aim of our study is a better understanding of (i) major sources of OM; (ii) biogeochemical factors which controlled BS formation; and (iii) whether high TOC reflect rather enhanced productivity or preservation of OM deposited during OAE 2. Furthermore, interpretations from the shallow setting in Wunstorf may also bridge the gap to a better understanding of the controls and effects of BS formation in the Proto-North Atlantic, the most prominent trap of organic carbon in the OAE 2.

\section{Geologic setting and previous works}

The village of Wunstorf is located ca. $25 \mathrm{~km}$ WNW of Hannover (Germany), and Cenomanian to Lower Turonian strata were drilled in 2006 (Erbacher et al., 2007; TK 25 Wunstorf, no. $3522,52^{\circ} 23.9420^{\prime} \mathrm{N}, 9^{\circ} 28.8240^{\prime} \mathrm{E}$; Fig. 1). During the Cenomanian, this area was part of a wide Eurasian epicontinental shelf sea, ranging from the shelf break west of England right onto the Russian Platform. It developed due to the worldwide Cenomanian transgression, which caused stepwise drowning of wide continental areas (Fig. 1) and the progressive establishment of nutrient-depleted shelf seas (Gale et al., 2000; Wilmsen et al., 2005). In basinal/subsident areas of the former north German shelf seas (Fig. 1), black marlstones with TOC contents up to ca. $2.5 \%$ (throughout the text referred to as black shales, BS) deposited in alternation with white nannofossil-rich limestones during the OAE 2 (C/T boundary event) and locally well into the Lower Turonian.These rocks are lithostratigraphically united in the Hesseltal Formation (Fig. 2). The Hesseltal Formation occurs in Westphalia and Lower Saxony (Hiss et al., 2007). Laterally, the Hesseltal Formation grades into red shell-detrital limestones of the Söhlde Formation, reflecting deposition on intra-shelf swells at water depths of only some tens of meters (Wiese, 2009). The black/white cyclicity in the Hesseltal 
Formation is the expression of an orbital modulation of deposition (Voigt et al., 2008a; Fig. 2). There are numerous works on its lithology, sedimentology, stratigraphy and macrofauna (Breitkreutz et al., 1991; Hilbrecht and Dahmer, 1994; Kriwet and Gloy, 1995; Voigt et al., 2006a, 2008a; Wood and Ernst, 1998), and recently, the Wunstorf section and the Wunstorf core (Fig. 2) were studied in detail by means of stable isotope geochemistry, orbital geochronology, inorganic geochemistry and palynology (Hetzel et al., 2011; Linnert et al., 2010; Prauss, 2006; Voigt et al., 2008a).

It needs to be emphasized that the definition of the OAE 2 is related to the well-documented positive OAE 2 carbon isotope excursion (OAE 2-CIE). In Wunstorf, the shift back to pre-OAE 2-CIE $\delta^{13} \mathrm{C}$ values occurs at about $36 \mathrm{~m}$ (Fig. 2). However, BS also developed after the excursion, and the last BS can be identified as a thin layer around $26 \mathrm{~m}$ already well in the Lower Turonian (Fig. 2).

\section{Material and methods}

\subsection{Sample material and sample preparation}

The cooled core samples were taken in 2011 at the IODP core repository in Bremen. Rock samples were then kept frozen until analyses. The samples were homogenized by grinding and aliquots were taken (see Fig. 2 for sampling depths) for bulk geochemical analyses and lipid extraction.

\subsection{Bulk analysis $(\mathrm{C} / \mathrm{N} / \mathrm{S})$ and $\delta^{15} \mathrm{~N}$}

Homogenized aliquots of the sample were analyzed for bulk C/N/S using a Hekatech Euro EA CNS analyzer. To determine the contents of TOC and carbonate carbon $\left(\mathrm{C}_{\mathrm{carb}}\right)$, each sample was also analyzed after acidification with hydrochloric acid. Bulk $\delta^{15} \mathrm{~N}$ isotope analysis was made in duplicate via elemental analysis-isotope ratio mass spectrometry (EAIRMS, Delta plus, Thermo Finnigan).

\subsection{Extraction and fractionation}

About $60 \mathrm{~g}$ of freeze-dried sediments were extensively extracted with dichloromethane/methanol (DCM/MeOH; 1/1; $\mathrm{v} / \mathrm{v})$ using ultrasonication. An aliquot of the combined extract was acetylated and analyzed for hopanols including 32,35-anhydrobacteriohopanetetrols (anhydroBHTs). Acetylation was performed using a mixture of acetic acid anhydride and pyridine $\left(1: 1, \mathrm{v}: \mathrm{v}, 50^{\circ} \mathrm{C}\right.$ for $1 \mathrm{~h}$ and overnight at room temperature). The pyridine/acetic acid anhydride mixture was then dried under vacuum. Another aliquot was separated by column chromatography into a hydrocarbon (F1), a ketone (F2), and an alcohol and polar fraction (F3; details are described in Blumenberg et al., 2009).

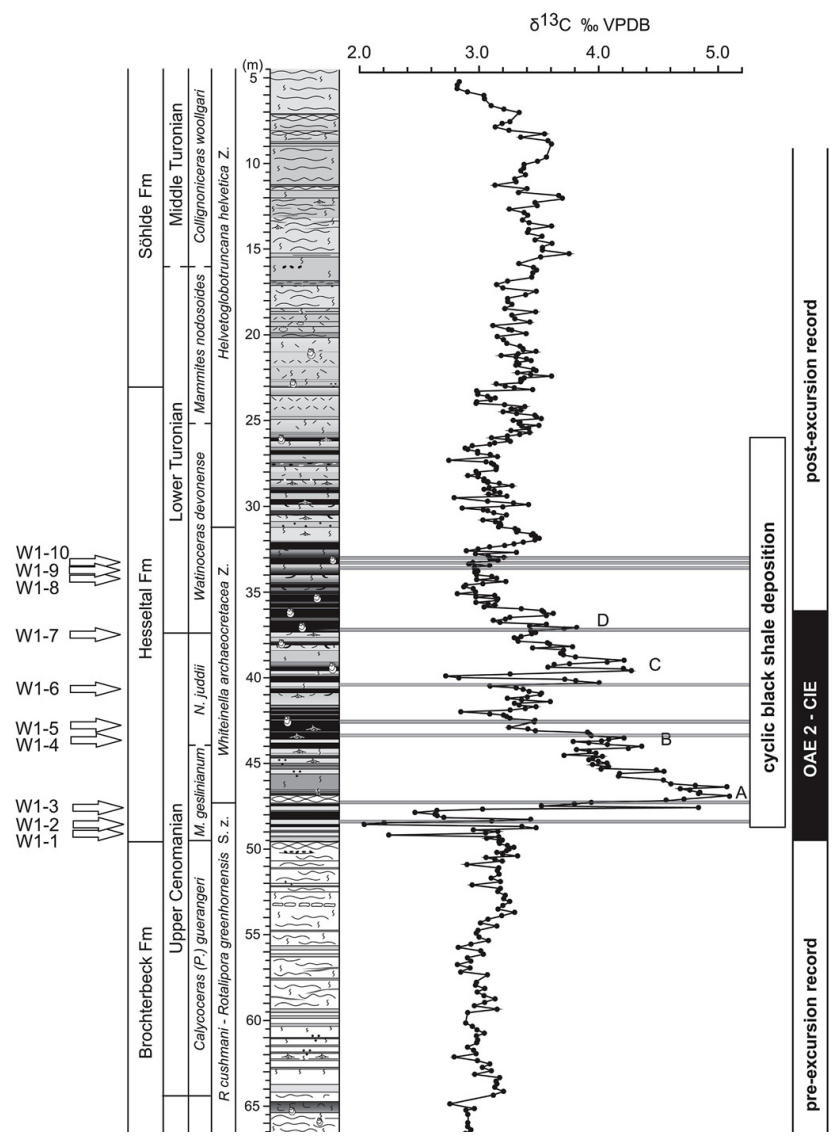

Fig. 2. Stratigraphy of the Wunstorf core used for the study and

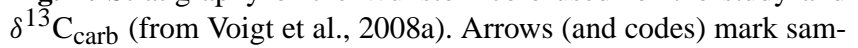
pling positions.

\subsection{Catalytic hydropyrolysis (HyPy)}

Catalytic hydropyrolysis (HyPy) experiments were conducted on selected samples using a system built by Strata Technology Ltd. (UK), which was manufactured based on the principals of catalytic HyPy (Love et al., 1995; Snape et al., 1989). This technique allows the cleaving of covalent bonds under a high hydrogen pressure with only minor artificial maturation (Love et al., 1995; Snape et al., 1989). Commonly, to about $0.5 \mathrm{~g}$ of rigorously Soxhlett extracted rock powder $(24 \mathrm{~h}$; DCM/MeOH; $1 / 1)$ about $50 \mathrm{mg}$ ammonium dioxydithiomolybdate $\left[\left(\mathrm{NH}_{4}\right) 2 \mathrm{MoO}_{2} \mathrm{~S}_{2}\right]$ catalyst were added. The pressure and flow rate of $\mathrm{H}_{2}$ were set at $15 \mathrm{MPa}$ and $51 \mathrm{~min}^{-1}$ respectively. The temperature was programmed as follows: Heating from ambient temperature to $250^{\circ} \mathrm{C}$ at $300^{\circ} \mathrm{C} \mathrm{min}^{-1}$, then to $500^{\circ} \mathrm{C}$ at $8^{\circ} \mathrm{C} \mathrm{min}^{-1}$. The pyrolysates were collected on a pre-extracted silica gel trap, which was immerged in dry ice. Pyrolysates were then separated into saturated and aromatic hydrocarbons using a previously described method (Blumenberg et al., 2012) and analyzed by GC-MS (see below). 


\subsection{Gas chromatography-mass spectrometry (GC-MS) and gas chromatography-combustion isotope ratio mass spectrometry (GC-C-IRMS)}

The hydrocarbon fractions (extract and after HyPy) and the ketone fractions after extraction were analyzed by GC-MS (Varian CP-3800 gas chromatograph coupled to a $1200 \mathrm{~L}$ mass spectrometer), and peaks were assigned by comparing mass spectra and retention times with published data and/or reference compounds. Gammaceran-3-one (tetrahymanone) was identified by comparison with published mass spectra (e.g., Barakat and Yen, 1990), and by co-injection with an authentic standard. The system was equipped with a fused silica column (Phenomenex Zebron ZB-5MS, $30 \mathrm{~m}$, $0.25 \mu \mathrm{m}$ film thickness, i.d. $0.32 \mathrm{~mm}$ ). It was used as carrier gas, and the temperature programme was $80^{\circ} \mathrm{C}(3 \mathrm{~min})$ to $310^{\circ}$ (held $25 \mathrm{~min}$ ) at $6^{\circ} \mathrm{C} \mathrm{min}^{-1}$. The MS source was operated at $200^{\circ} \mathrm{C}$ in electron impact mode at $70 \mathrm{eV}$ ionisation energy. Fractions were injected on column using a PTV injector. The injector was initially held at $80^{\circ} \mathrm{C}$ for $0.2 \mathrm{~min}$ and then heated at $150{ }^{\circ} \mathrm{C} \mathrm{min}^{-1}$ to $320^{\circ} \mathrm{C}$ (held for $15 \mathrm{~min}$ ). Biomarkers were commonly analyzed in total ion current mode (from 50 to $650 \mathrm{amu}$; TIC), and for selected hydrocarbon fractions by selected ion monitoring (SIM) of nine ions (total cycle time $0.9 \mathrm{~s}$ ), and by multiple reaction monitoring (MRM) with a total cycle time of $1.6 \mathrm{~s}$ per scan for 16 transitions (see Blumenberg et al., 2012, for details). Argon was used as the collision gas. The collision energy was $-10 \mathrm{eV}$.

To analyze GC-amenable acetylated polyfunctionalized lipids (i.e., anhydroBHTs), high temperature GC was performed on a CP-3800 GC connected to a Saturn 2000 Ion Trap (both Varian). The GC was equipped with a VF5-HT ( $15 \mathrm{~m}$ length, $0.32 \mathrm{~mm}$ ID, $0.1 \mu \mathrm{m}$ film thickness; temperature program for HT-GC-MS was $1 \mathrm{~min}$ at $50^{\circ} \mathrm{C}$; from 50 to $200^{\circ} \mathrm{C}$ at $15^{\circ} \mathrm{C} \mathrm{min}^{-1}$ (held for $1 \mathrm{~min}$ ), from 200 to $250^{\circ} \mathrm{C}$ at $10^{\circ} \mathrm{C} \mathrm{min}^{-1}$ (held for $1 \mathrm{~min}$ ), and from 250 to $350^{\circ} \mathrm{C}$ at $5^{\circ} \mathrm{C} \mathrm{min}^{-1}$ (held for $8 \mathrm{~min}$ ). The ion trap and transfer line temperatures were $175^{\circ} \mathrm{C}$ and $350^{\circ} \mathrm{C}$, respectively. AnhydroBHTs were identified in comparison with published mass spectra (Bednarczyk et al., 2005) and MRMs specific for desmethyl and ring A methyl hopanoids. Elution characteristics of 2- and 3-methylated hopanoids on the VF5-HT column were tested by analysing acetylated extracts including 2- and 3-methylated diplopterol and BHT (from Beijerinckia indica and Gluconacetobacter xylinum). As shown in Fig.7, 2-methyl hopanoids elute slightly before and 3-methyl hopanoids after the desmethylated analogue. The $\delta^{13} \mathrm{C}$ values of selected compounds were also analyzed. Details of the analytical procedure can be found elsewhere (Blumenberg et al., 2010).

\section{Results}

\subsection{Bulk geochemical data}

Figure 3 shows the amounts of total organic carbon (TOC) compared to the $\delta^{13} \mathrm{C}_{\text {carb }}$ reported by Voigt et al. (2008a). Both are well-correlated. However, highest TOC abundance of $1.8 \%$ was found in the sample taken at $33.10 \mathrm{~cm}$ (W19) well above the OAE 2-CIE (Fig. 2). Similar values were found in BS layers in between, whereas the lowest values correspond to low $\delta^{13} \mathrm{C}_{\text {carb }}$ with TOC as low as $0.07 \%$ (lowermost sample; W1-1). Thus, BS formation is generally linked to positive $\delta^{13} \mathrm{C}_{\text {carb }}$ values. TOC/S ratios were mostly lowest at times of increased TOC values (TOC/S: 1 to 2.5), but were generally low in the upper OAE 2 . In the lower OAE 2 and above (at $20.08 \mathrm{~cm}$; W1-11) values exceed 20. Figure 3 also demonstrates TOC/N ratios and $\delta^{15} \mathrm{~N}$ values, which are both negatively correlated. Cross plotting of TOC and $\delta^{15} \mathrm{~N}$ demonstrates a good negative correlation (Fig. 4).

\subsection{Extractable biomarkers}

The highest abundance of biomarkers was found in the black shales. Total ion chromatograms (TIC) of the hydrocarbon (F1) and ketone (F2) fraction of one representative sample - taken within the OAE 2 (W1-9) are shown in Fig. 5. In addition to $n$-alkanes, hydrocarbons consist of sterenes, hopenes, and homohopanes in the F1. Homohopanes were dominated by $17 \beta(\mathrm{H}), 21 \beta(\mathrm{H})$ homohopane, while higher homohopanes of up to $\mathrm{C}_{35}$ were only present in trace amounts (not visible in TIC, Fig. 5). The relative amounts of $\mathrm{C}_{32}$ to $\mathrm{C}_{35}$ homohopanones, however, were higher than for homohopanes, but highest relative amounts were also found for $17 \beta(\mathrm{H}), 21 \beta(\mathrm{H})$ homohopanone. The latter suggests pentafunctionalized bacteriohopanepolyols as a major source, while $17 \beta(\mathrm{H}), 21 \beta(\mathrm{H})$ homohopane has most likely the ubiquitous tetrafunctionalized BHPs as an origin (Farrimond et al., 2000). The distribution of homohopanoids is mostly comparable between hydrocarbon and ketone fractions [order of abundances exemplified for W1-9 in Fig. 6; ketones (diagenetically related hydrocarbons in brackets): $\beta \beta \mathrm{H} 31$-one $(\beta \beta \mathrm{H} 30) \approx$ $\beta \beta \mathrm{H} 32$-one $(\beta \beta \mathrm{H} 31)>\beta \beta \mathrm{H} 30$-one $(\beta \beta \mathrm{H} 29)]$. Additional hopanes, also resembling higher maturities (particularly $\alpha, \beta$ isomers), were found in the hydrocarbon fraction (Fig. 6). Slightly eluting before $17 \beta(\mathrm{H}), 21 \beta(\mathrm{H})$-hopanone, another $\mathrm{C}_{30}$-pentacyclic triterpenanone was observed, which was identified as tetrahymanone (syn. gammacerane-3-one).

To detect polyfunctionalized bacteriohopanepolyols (BHPs), high temperature GC-MS of acetylated total lipid extracts were performed. In most samples, anhydroBHT was found, while the common bacteriohopanetetrol (BHT) was lacking (example of a HT-GC-MS TIC shown in Fig. 7). In BS samples, high abundances of $17 \beta(\mathrm{H}), 21 \beta(\mathrm{H})$ trishomohopanol, 2- and 3-methylated anhydroBHT, and a 


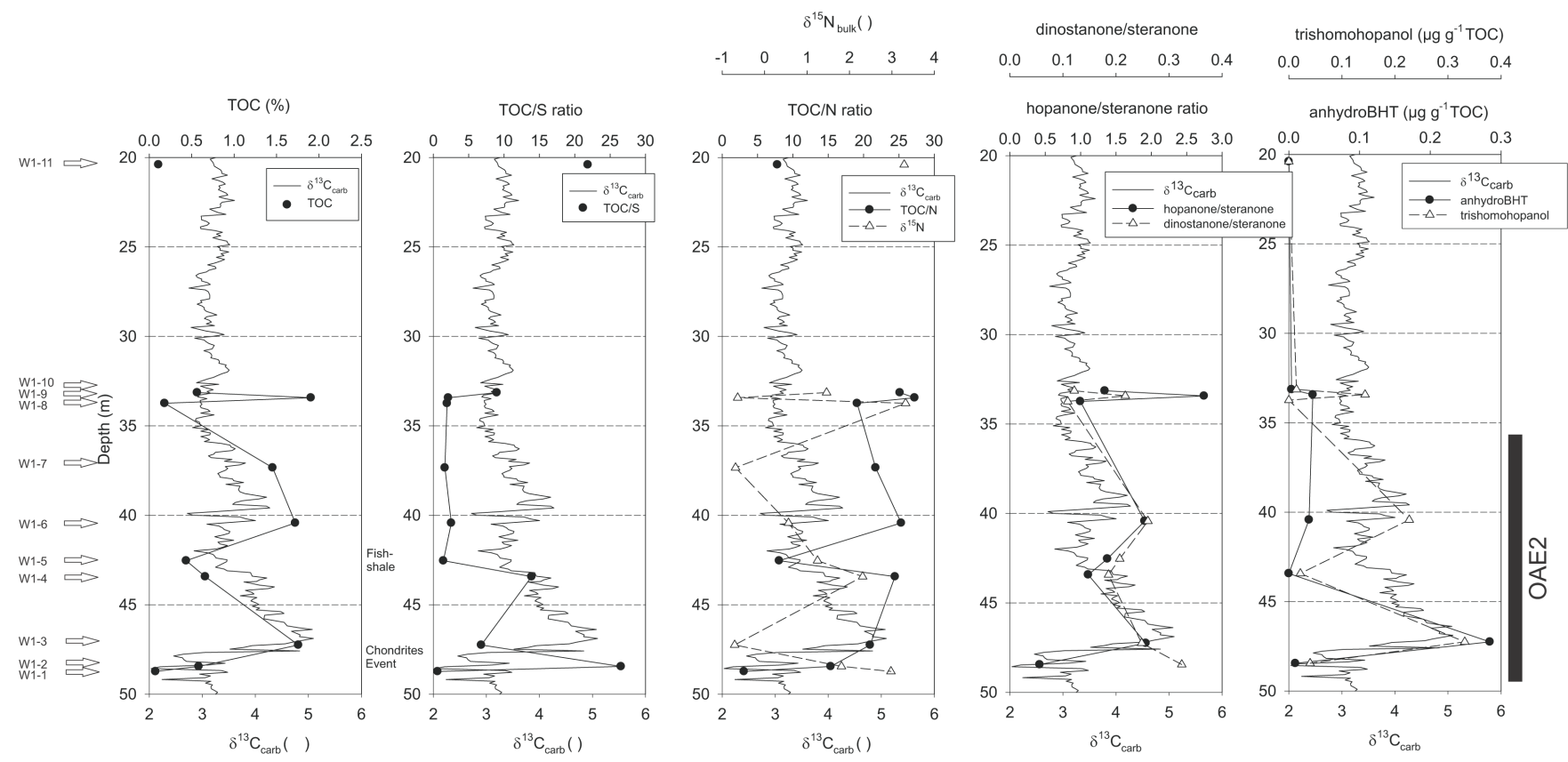

Fig. 3. Biogeochemical (three left) and biomarker (two right diagrams) data of the samples studied compared to the $\delta^{13} \mathrm{C}_{\text {carb }}($ from Voigt et al., 2008a). Left codes are sample names. Selected biomarker ratios and hopanoid concentrations in the extractable organic matter are shown in the two right diagrams.

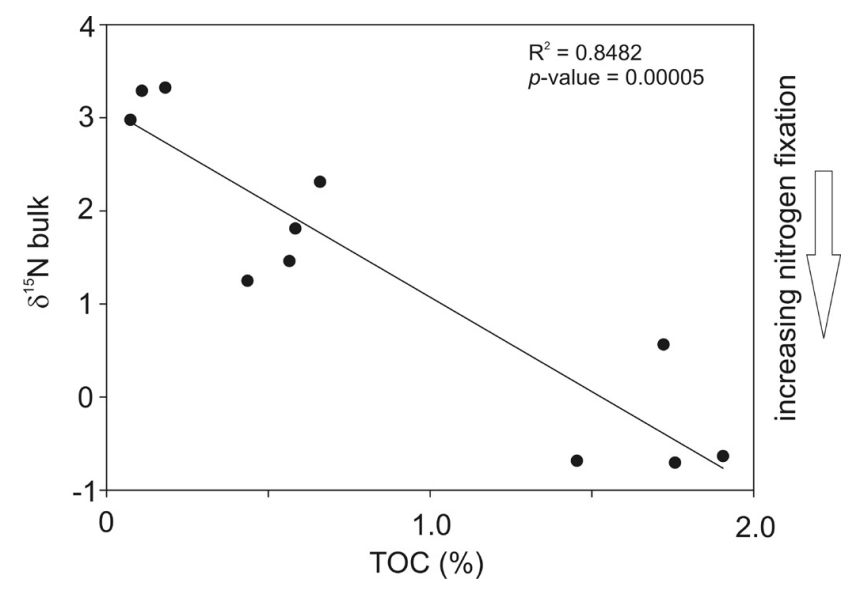

Fig. 4. Cross plot of $\delta^{15} \mathrm{~N}$ bulk values with TOC concentrations, indicating that black shale formation is linked to increasing importance of nitrogen fixation (decreasing $\delta^{15} \mathrm{~N}$ ). $p$-values represent a Spearman rank order correlation.

trifunctionalized anhydroBHT $(m / z 449$, tentatively identified from comparisons with published mass spectra in Talbot et al., 2005) were observed. These biomarkers were found only in low amounts or they were under detection limit in non-BS samples, respectively. Ring A methylated hopanoids were also present in other fractions (in hydrocarbons and ketones).

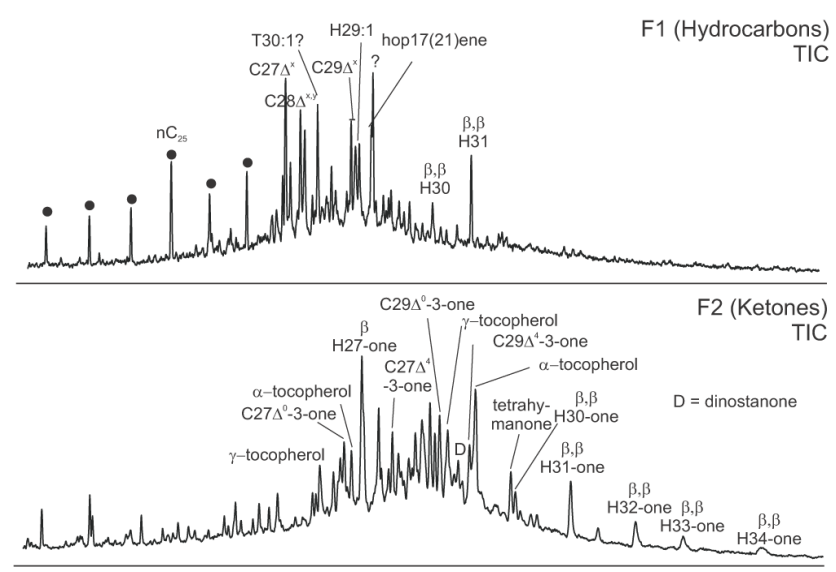

Fig. 5. Biomarkers in the extractable organic matter of sample W19 (total ion chromatograms of the hydrocarbons (F1) and the ketone (F2) fraction). Compounds with $\mathrm{C}$ represent steroids, $\mathrm{H}$ hopanes, and $\mathrm{T}$ unknown triterpenoids. Numbers refer to the carbon skeleton. $\Delta^{\text {number or } x}=$ double bond position $(x=$ unknown $)$.

Various tocopherol derivatives, most likely of photoautotrophic origin, were present in BS samples. Sterenes consisted mainly of cholestane and 24-ethylcholestane derivatives. Steroidal ketones were also observed in similar distribution as sterenes in the hydrocarbons. However, although dinosterane was also observed in trace amounts, relative abundances of dinostanone $(4 \alpha, 23,24$-trimethyl$5 \alpha$-cholestane-3-one) were much higher. Figure 3 shows 


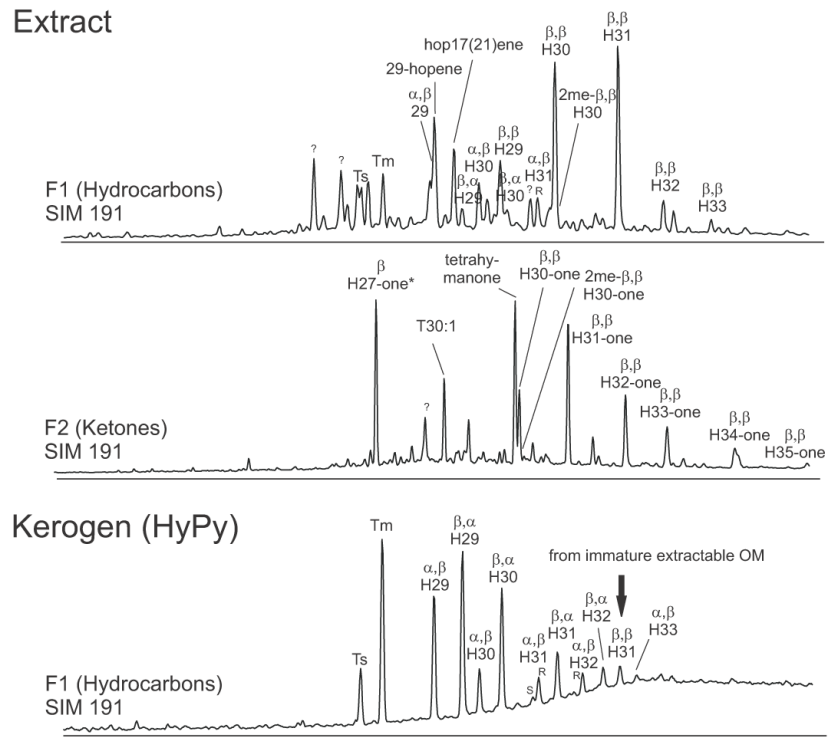

Fig. 6. Hopanoids in different fractions in the sample W1-9 (exemplified). In the upper part hydrocarbons (F1) and ketones (F2) in the extractable organic matter are shown. In the lower part hydrocarbons released from the kerogen are presented (making up more than $95 \%$ of the total lipid OM in the samples). *22,29,30-trisnorhopane-21-one was tentatively identified based on published data (Barakat and Yen, 1990). Ts $=22,29,30$-trinor-18 $\alpha$ neohopane, $\mathrm{Tm}=22,29,30$-trinor-17 $\alpha$-hopane. Compounds with $\mathrm{H}$ represent hopanes and $\mathrm{T}$ unknown triterpenoids. Numbers refer to the carbon skeleton. Greek letters abbreviate $\mathrm{H}$ isomerisation at carbon atoms 17 and 21 .
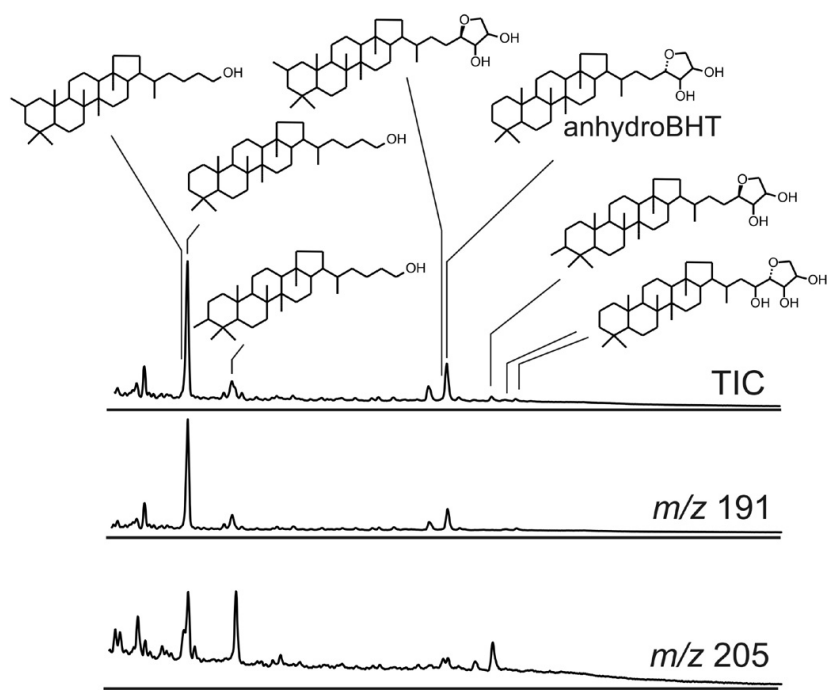

Fig. 7. Hopanols in the F3 of sample W1-3 (exemplified) shown as total ion chromatogram (TIC) and as selected ions specific for hopanols $(m / z$ 191) and ring A-methylated hopanols $(m / z$ 205). The largest peak in the suite of anhydroBHTs is the common $17 \beta(\mathrm{H}), 21 \beta(\mathrm{H})$-anhydroBHT.
Table 1. Maturities of biomarkers released by catalytic HyPy.

\begin{tabular}{lccc}
\hline Sample & $\begin{array}{c}R_{\mathrm{c}} \\
(\text { MPI-1) }\end{array}$ & $\begin{array}{c}\mathrm{C}_{22} \mathrm{~S} / \mathrm{R} \\
(\text { for C32) }\end{array}$ & $\begin{array}{c}17 \alpha \text {-hopane/(17 } \beta \text {-mor. } \\
+17 \alpha \text {-hopane) }\end{array}$ \\
\hline W1-10 & $1.00^{\mathrm{a}}$ & - & - \\
W1-9 (BS; above OAE 2) & $1.05^{\mathrm{a}}$ & $0.15^{\mathrm{b}}$ & $0.26^{\mathrm{b}}$ \\
W1-8 & $0.94^{\mathrm{a}}$ & - & - \\
W1-3 (BS; OAE 2) & $1.03^{\mathrm{a}}$ & $0.5^{\mathrm{b}}$ & $0.34^{\mathrm{b}}$ \\
\hline
\end{tabular}

$\mathrm{BS}=$ black shale; ${ }^{\mathrm{a}}$ peak to late oil, ${ }^{\mathrm{b}}$ immature (after Killops and Killops, 2005), $-=$ below detection limit. For position of the samples refer to Fig. 2.

the relative distribution of hopanones (cyanobacteria) to steroidal ketones (algae) and dinostanone (dinoflagellates) to steroidal ketones. Except for sample W1-1, both correlate excellently, demonstrating highest relative abundance of bacteria and dinoflagellates during deposition of BS. AnhydroBHTs (maximum $280 \mathrm{ng} \mathrm{g}^{-1}$ TOC) and $17 \beta(\mathrm{H}), 21 \beta(\mathrm{H})$ trishomohopanol (maximum $330 \mathrm{ngg}^{-1}$ TOC) were also highest during $\mathrm{BS}$ deposition. Based on the relative occurrence of 2-methylated versus non-methylated hopanoids, 2methyl hopanoid indices (Summons et al., 1999) were calculated for the different fractions. The 2-methyl hopane indices for hydrocarbons were from 12 to $24 \%$ high (Summons et al., 1999). Interestingly, the lowest 2-methyl hopane indices were calculated for BS horizons. Using anhydroBHTs, lower 2-methyl hopanoid indices of up to $4 \%$ were calculated, and maxima correlated positively with the TOC contents (Fig. 8a). This is contrary to 2-methyl hopane indices calculated from hydrocarbons (Fig. 9).

The presence of isorenieratene and other carotenoids from green sulfur bacteria was tested by using SIM and MRM. Neither isorenieratane nor other related carotenoids were found in the kerogen and in the extractable organic matter.

$\delta^{13} \mathrm{C}$ values of biomarkers were also analyzed, but are not shown in detail. Values were not depleted in ${ }^{13} \mathrm{C}$ (maximizing at $-35 \%$ VPDB). Values of biomarkers in samples taken within the upper OAE 2 demonstrated slight enrichments in ${ }^{13} \mathrm{C}$ compared to the samples below and above the OAE 2 (up to $5 \%$ difference).

\subsection{Composition of kerogens}

The Soxhlett extracted residues of selected samples (W1-3, W1-8, W1-9, and W1-10) were subjected to catalytic hydropyrolysis (HyPy) to release covalently bound biomarkers from the macromolecular matrix. Generally, the relative abundance of GC-amenable kerogen-bond hydrocarbons (exemplified for W1-9 shown in Fig. 10) was found to be about 20 times higher than that of the extractable OM, demonstrating a significant portion of OM to be non-amenable to classical extraction approaches. Distributions of kerogen-released biomarkers were found to be characteristic to each sample facies and in part strongly different to the bitumens. The maturity of the samples was calculated on the relative abundance of phenanthrene and methylphenanthrenes $\left[R_{\mathrm{c}}\right.$ (MPI-1)] and 

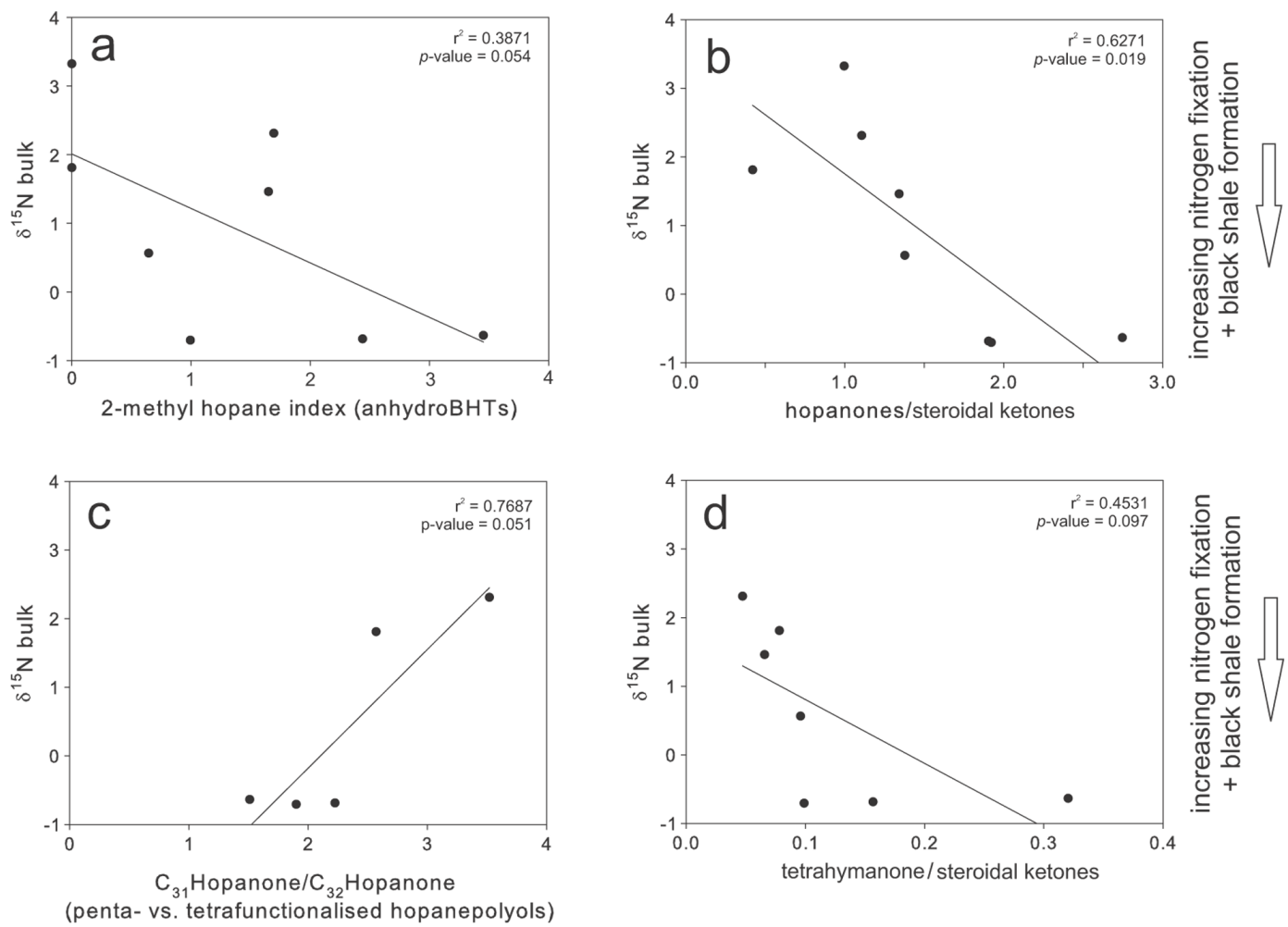

Fig. 8. Cross plot of $\delta^{15} \mathrm{~N}$ bulk values with selected biomarker ratios. p-values represent a Spearman rank order correlation.
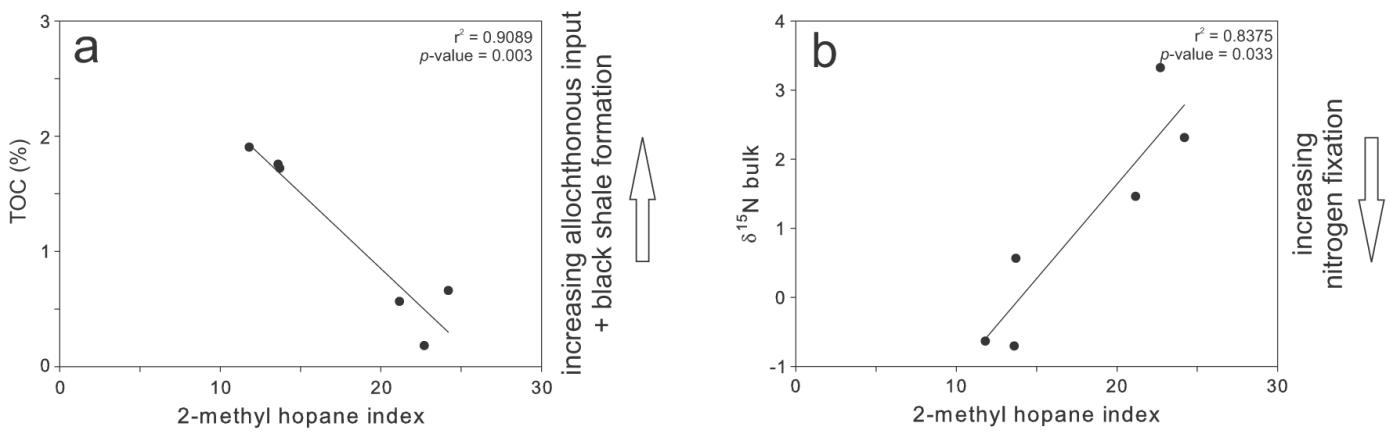

Fig. 9. Cross plot of TOC (a) and $\delta^{15} \mathrm{~N}$ bulk (b) versus 2-methyl hopane indices, respectively (based on hydrocarbons in extractable organic matter). The negative correlation with TOC and positive correlation with $\delta^{15} \mathrm{~N}$ indicates that 2-methyl hopane abundances were diluted by other allochthonous non-ring A methylated hopanes during periods of black shale formation (characterized by high TOC). p-values represent a Spearman rank order correlation.

were found to be high (Table 1). It was much higher than the maturity calculated from biomarkers in the bitumen (not shown), where aromatic hydrocarbons were absent. Maturities in different compound classes of the kerogen were also different. For instance, much lower values for $\mathrm{S}$ isomerisation at $\mathrm{C}_{22}$ of hopanes $(0.15)$ than expected from maturities in the aromatics (expected 0.6) were found. Hopanes released from the kerogen also contain $\beta, \beta$-isomers along with moretanes ( $\beta, \alpha$; Fig. 6), a feature, which also does not fit to the much higher maturities calculated from aromatic hydrocarbons. This indicates that only a portion of the hopanes in the kerogen is indigenous to autochthonous production (e.g., $\beta \beta \mathrm{H} 31$; Fig. 6). In accordance with an allochthonous component in the kerogen, 2-methyl hopanes were not found in the kerogen-compounds which were abundant in the bitumen. Tricyclic triterpenoids were found neither in the extractable OM nor after HyPy. Diasteranes were not detected in any of the samples, demonstrating the majority of steranes to be immature. 


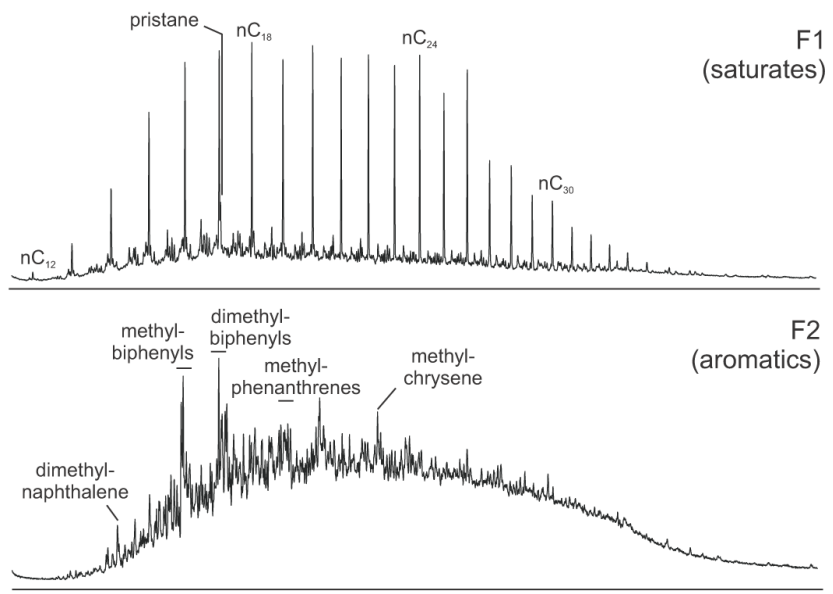

Fig. 10. Total ion chromatograms (TICs) of the saturate and aromatic fraction of the BS sample W1-9. HyPy released about 5 times more aromatic than saturated hydrocarbons.

\section{Discussion}

\subsection{Sources for organic matter during BS deposition in the OAE 2 at Wunstorf}

Our biomarker data show that bacteria and organic-walled dinoflagellates (and, less important, calcareous nannoplankton) are the main sources of extractable organic matter in the $\mathrm{BS}$ (independent of whether they formed during the OAE 2 or later). Bacterial OM is evidenced by the occurrence of hopanoids, including functionalized structures (hopanones, hopanols and 32,35-anhydrobacteriohopanetetrols (anhydroBHTs)). The most common bacteriohopanepolyol (BHP), bacteriohopanetetrol (BHT), and other BHPs were not found in Wunstorf, most likely because they were already degraded. AnhydroBHTs are diagenetically relatively stable and are products of bacteriohopanepolyols (Bednarczyk et al., 2005; Schaeffer et al., 2008, 2010). Despite the relatively high stability of anhydroBHTs, there is only one report of anhydroBHT in rocks older than the Cenozoic (from the Gorodische; Upper Jurassic; Bednarczyk et al., 2005), and thus the findings here represent the second oldest record of this biomarker.

Among ring A methylated functionalized hopanoids, 3methylated structures were found to be most abundant (Fig. 7). 3-methyl hopanoids were reported from aerobic methanotrophic and acetic acid bacteria (Rohmer et al., 1984; Zundel and Rohmer, 1985). In all fractions of the extractable OM, 2-methyl hopanoids were partially abundant (including anhydroBHTs; Fig. 7) with 2-methyl hopane indices of more than $20 \%$. Moreover, the abundance of 2-methyl anhydroBHTs correlates negatively with bulk $\delta^{15} \mathrm{~N}$ (Fig. 8), which itself correlates well with TOC (Fig. 4). Bulk $\delta^{15} \mathrm{~N}$ can be affected by diagenetic overprint. It was demonstrated that during laboratory experiments under oxic conditions bulk $\delta^{15} \mathrm{~N}$ increases (Lehmann et al., 2002), a potential explanation for the relatively high $\delta^{15} \mathrm{~N}$ observed in non-BS in Wunstorf. However, at the same time, TOC/N ratios were also observed to increase (Lehmann et al., 2002), the opposite to what we observed in the Wunstorf core (Fig. 3). We therefore surmise that bulk $\delta^{15} \mathrm{~N}$ in Wunstorf record those from primary production and low values to represent enhanced nitrogen fixation (e.g., Sachs and Repeta, 1999). The high relative abundances of 2-methyl anhydroBHTs suggest a biogeochemical situation preferring 2-methyl hopanoid producers (and/or production). Commonly, cyanobacteria are regarded as a source for 2-methyl hopanoids (Summons et al., 1999). However, other sources for 2-methyl hopanes are also known. These include methanotrophic, methylotrophic and soil bacteria (Bisseret et al., 1985; Renoux and Rohmer, 1985; Bravo et al., 2001). For the Wunstorf BS, a methanotrophic origin is unlikely because none of the hopanoids demonstrated ${ }^{13} \mathrm{C}$-depletions, which are common for biomasses produced by methanotrophic bacteria (e.g., Jahnke et al., 1999). Soil bacteria are also unlikely because 2-methyl anhydroBHT was highest when other marine primary producers flourished (e.g., dinoflagellates; see discussion below). An anoxygenic phototrophic bacterium, Rhodopseudomonas palustris, was also reported as a source for 2-methyl hopanes, accompanied by tetrahymanol and 2-methyl tetrahymanol (Kleemann et al., 1990; Rashby et al., 2007). In Wunstorf, an oxidation product of the $\mathrm{C}_{30}$ pentacyclic triterpenoid tetrahymanol (Kleemann et al., 1990; Ten Haven et al., 1989), gammaceran-3-one, is present in high amounts, but 2-methyl tetrahymanol is lacking. Therefore, ciliates are the most likely major source of tetrahymanol the Wunstorf sediments (Ten Haven et al., 1989), which commonly graze at interfaces of stratified water bodies (Sinninghe Damsté et al., 1995; Ten Haven et al., 1989). Moreover, this also points at cyanobacteria as the major contributors of 2-methylated functionalized hopanoids (although methylotrophs can not be excluded). To get further insights into the importance of specific cyanobacterial groups during OAE 2 BS formation, ratios of the different classes of BHPs were calculated based on hopanone distributions. Generally, hexafunctionalized BHPs degrade preferentially to $\mathrm{C}_{30}$-hopanones, pentafunctionalized to $\mathrm{C}_{31}$-hopanones and tetrafunctionalized to $\mathrm{C}_{32}$-hopanones (Rohmer et al., 1984). Particularly the second and most likely also the first, are specific for cyanobacteria (Talbot et al., 2008, and references therein). Although the database for the plots is low, we plotted the relative abundance of diagenetical products of pentafunctionalized $\left(\mathrm{C}_{31}\right)$ and hexafunctionalized $\left(\mathrm{C}_{32}\right)$ hopanoids against $\delta^{15} \mathrm{~N}$. Surprisingly, both relationships are positively correlated (Fig. 8c; exemplified shown for $\mathrm{C}_{31}$ ), demonstrating lower abundance of respective source bacteria during periods of possibly high nitrogen fixation activity. If major sources for both BHP classes also originated from cyanobacteria, they had apparently different sources than those of 2-methyl 
hopanoids, which appear to be related to high nitrogen fixation.

Dinosterol (and the degradation products dinosterane or dinostanone; $4 \alpha, 23,24$-trimethyl-5 $\alpha$-cholestane-3-one) is an excellent biomarker for dinoflagellates (Summons et al., 1987). In accordance with bacterial hopanoids and in contrast to algae producing 4-desmethyl steroids (e.g., calcareous nannoplankton), dinosterol-producing dinoflagellates were found to be highly abundant in most of the samples, and the relative abundance of dinostanone compared to steroidal ketones correlates well with BS formation (Fig. 3). A good adaptation of specific dinoflagellates to the conditions during OAE 2 and particularly during BS formation was also observed in micropaleontological studies (Linnert et al., 2010; Prauss, 2006). In these studies, Cyclonephelium membraniphorum, which is thought to flourish in abundance under harsh surface-water conditions induced by anoxia (Marshall and Batten, 1988), was reported to dominate the dinoflagellate community. Further indications for high contributions of algae to the OM of the Wunstorf BS in general come from HyPy data of kerogens. The relative abundance of HyPy released biomarkers was about 20 times higher than the extractable OM. HyPy of selected Wunstorf samples released aliphatic hydrocarbons with carbon numbers from 12 to 37 (Fig. 10). The respective distributions are different than those in the related extractable organic matter, which is a common feature in immature rocks (e.g., Love et al., 1998, and references therein), mirroring different sources for the majority of bitumen and macromolecular organic matter in respective rocks. A mixture of allochthonous and autochthonous portions in the macromolecular OM is also likely for the Wunstorf samples (see below). High abundances of aliphatic hydrocarbons in the kerogen, only slight even over odd predominances of carbon chain numbers in the $n$-alkanes, and a virtual absence of acyclic isoprenoids like phytane and pristane has been frequently reported from biomacromolecules of calcitrant aliphatic biomolecules from specific algae. These include the freshwater algae Botryococcus braunii and marine microalgae (e.g., Berkaloff et al., 1983; Derenne et al., 1992). In Wunstorf, however, palynomorphs of Botryococcus were low in numbers (Prauss, 2006; M. Prauss, personal communication). We therefore favor marine algae as the major source for alkyl dominated kerogens at Wunstorf. Abundant algae in the Wunstorf setting were the Chlorophyta Pterospermopsis and Tasmanites (Prauss, 2006). The latter, however, is less likely since Tasmanites produces tricyclic triterpenoids (Greenwood et al., 2000), which were absent in Wunstorf. Algae might have also contributed to the aromatic hydrocarbons bond in the kerogen. In the organicrich samples W1-3 and W1-9, aromatic hydrocarbons were highly abundant and shared similar distributions with mainly low molecular weight $\mathrm{HCs}$ and a prominent underlying unresolved complex mixture (see Fig. 10). In these samples, the aromatic parts of the kerogen may be interpreted in two ways or a mixture of both origins: mainly as an input of allochthonous degraded terrestrial organic matter, which is commonly highly aromatic due to the input from lignin (e.g., van de Meent et al., 1980). An allochthonous source may indeed explain parts of the aromatics, particularly because maturities calculated from MPI-1 are too high to fully reflect immature autochthonous biomacromolecules from microalgae (Table 1) and because of differences between biomarker distributions in kerogen and extracts (e.g., lack of dinosterane and 2-methyl hopanes in HyPy products). However, an autochthonous origin of the aromatic portion of the macromolecular OM is also likely. Aromatic subunits are occasionally reported from biomacromolecules of marine alga, such as Chlorella (Derenne et al., 1996), dinoflagellate resting cysts (Kokinos et al., 1998; although recently questioned by Versteegh et al., 2012), and acritarchs (Arouri et al., 2000; Marshall et al., 2005). All these groups were recorded from Wunstorf (Prauss, 2006) and are good candidates for an input of aromatic units into the kerogen matrix. Notwithstanding the definite origin, our data suggest that, along with bacteria, algae also contributed significantly to OM in the Wunstorf BS.

\subsection{Triggers for high organic carbon accumulation}

Geochemical data suggest that BS formation in Wunstorf occurred under bottom-water suboxia (and anoxia in the upper sediment; Hetzel et al., 2011). Our data also suggest that periods with high productivity most likely induced anoxia in the bottom-waters during BS deposition. Periodical anoxia is supported by a lack of bioturbation (Hilbrecht and Dahmer, 1994) and of benthic foraminiferas (Friedrich et al., 2011), and low ratios of TOC to sulfur (Fig. 3), of which the latter is indicative of euxinia (Berner, 1984; Morse and Emeis, 1990). Moreover, it is also shown that protective mechanisms of the macromolecular organic matter from clay minerals are important factors for the high abundance of OM, particularly for BS (Salmon et al., 2000). However, this process appears to be of minor importance for OAE BS as SEM-EDS study revealed respective organic matter to be mainly composed of fragments and "chunks" and not of finely dispersed material on clay layers (Ohkouchi et al., 2003). Supportive for mainly production-induced anoxia in Wunstorf is the finding of distinct communities reflected in BS and interbedded calcareous nannoplankton limestones. BS-specific is an increase in cyanobacteria over calcareous nannoplankton (enhanced hopanone/steroidal ketones and 2-methyl anhydro BHTs ratios; Fig. 8a, b), dinoflagellates (dinostanone; Fig. 3) and ciliates (tetrahymanone; Fig. 8d). Although not mirrored by the usually algal-derived 4-desmethylated steroidal ketones, algal OM was also higher during BS formation. This is indicated by the high amounts of most likely algal derived biomacromolecules released by catalytic HyPy. Together, this may be indicative of a productivity-induced formation of BS due to biogeochemical short-term triggers of enhanced growth of these organisms (e.g., by enhanced input of P from 


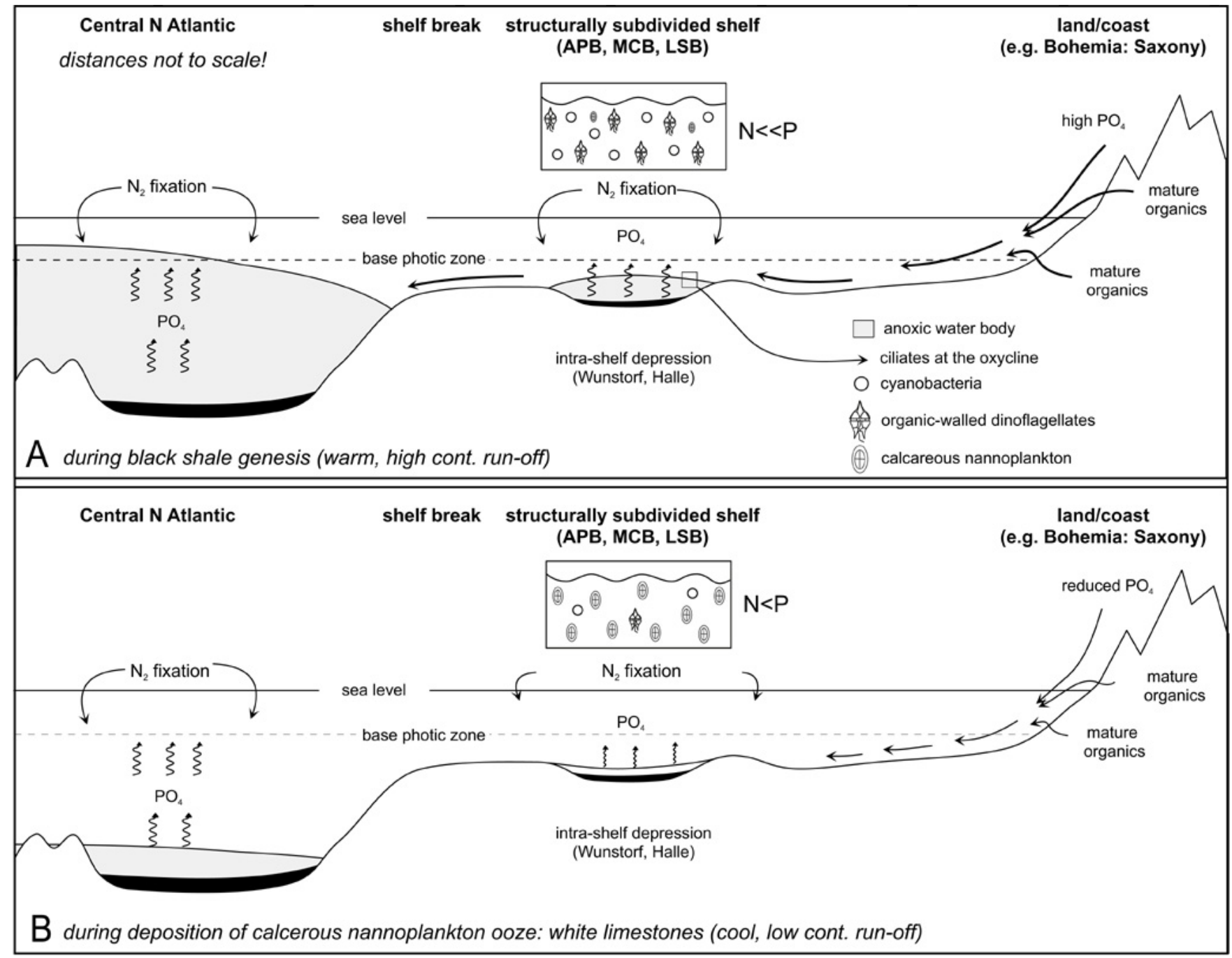

Fig. 11. Biogeochemical situations prevailing during black shale and carbonate deposition at Wunstorf in the context of other OAE 2 settings. The changes in N/P ratios are given in relationship to the Redfield ratio (16/1). The scenario of enhanced nitrogen fixation and temporal photic zone anoxia for the Central N Atlantic was inferred from previous reports (Kuypers et al., 2002, 2004; Sinninghe Damsté and Köster, 1998; Pancost et al., 2004). APB: Anglo-Paris Basin; MCB: Münsterland Cretaceous Basin; LSB: Lower Saxony Basin.

continental run-off). A respective scenario for the OAE 2, also including enhanced growth of algae, has recently been presented (Higgins et al., 2012). Moreover, in addition to the two above mentioned scenarios, a third trigger is apparent in Wunstorf: a significant input of allochthonous OM. As already described above, 2-methyl hopanoids were found in almost all samples and fractions analyzed but they were absent in biomarkers released from the kerogen by catalytic hydropyrolysis. This situation was also observed for dinosterol derivatives. Moreover, the relation of 2-methyl hopane hydrocarbon indices to TOC demonstrates lowest values during times of high TOC accumulation (Fig. 9a). As shown from 2-methyl anhydroBHT (Fig. 8a), this does not correspond with lower production of 2-methyl hopanoids during these times. More likely, the samples showing the highest 2- methyl hopane indices (and, thus, indices as well) were influenced by strong inputs of allochthonous organic matter. This added degraded material rich in (hopanoid) hydrocarbons but with low 2-methyl hopane abundances. This situation obscured the autochthonous OM contributions, which were indeed rich in 2-methylated functionalized hopanoids (Fig. 8a). In addition, the maturities within the kerogen bond biomarkers and in comparison with extractable OM were also conflicting. Maturities calculated on aromatic hydrocarbons are much higher than those calculated on the freely extractable hopanes. Together this indicates that - along with considerable autochthonous algal OM - parts of the biomacromolecules were transferred to the intra-shelf depression in Wunstorf (Fig. 11). Due to the recalcitrant nature of kerogen (Hedges, 1992), mature kerogen can be transported over 
long distances. Thus, it is simple to derive the OM, e.g., from the Bohemian Massive. There, expanded estuary and fluvial valleys drowned during the Upper Cenomanian transgression (Ulicný et al., 1997), and the transgressive surge might have reworked considerable amount of organic matter.

\subsection{The OAE 2 in the Wunstorf setting - a biogeo- chemical productivity scenario}

This study points to further problems in interpreting OAE 2 from shelf settings. Looking at the Hesseltal Formation as deposited in Westphalia and Lower Saxony (Germany) in special or other OAE 2 in general, BS are often interpreted to represent eutrophic conditions in conventional views (Hadras and Mutterlose, 2007; Linnert et al., 2010), while the white intercalated calcareous nannofossil limestones are - as in the case of the underlying Brochterbeck Formation (Fig. 2) - seen to result from biomineralisation in oligotrophic surface waters (Linnert et al., 2010; Wilmsen et al., 2005). These terms, however, are misleading as they are simply nonquantitatively/non-proportionally used to indicate low and high availabilities of nutrients irrespective of its composition and its origin (internal cycling vs. continental run-off).

In the case of the Wunstorf area, the nearest coasts and the shelf edge were hundreds kilometers away during the deposition of the Brochterbeck Formation (Fig. 1). As the OAE 2 is associated with a transgressive pulse of about $25 \mathrm{~m}$ within only 80 to $180 \mathrm{kyr}$. (Voigt et al., 2006b), the coastlines migrated rapidly further away from the Wunstorf area, minimizing the nutrient input by rivers or by upwelling even more. Thus, the depositional area should have been characterized by a persisting highly $\mathrm{N}$-limited biosedimentary system like the Brochterbeck Formation with very high internal recycling rates as observed in today's open oceanic settings (e.g., Duarte and Agustí, 2011). However, the OAE 2 is associated with a sedimentary phosphorus peak (Hetzel et al., 2011; Mort et al., 2007), also in settings without BS development (e.g., the Helvetic Shelf; Westermann et al., 2010). Parts of the P excursion in BS settings can be explained by a decreasing retention potential of $\mathrm{P}$ in organic rich deposits (Mort et al., 2007). On the other hand, Flögel et al. (2011, with references therein) suggested that the volcanogenic high $p \mathrm{CO}_{2}$ led to increased continental silicate weathering during OAE 2 and an increased phosphorus load to the oceans. Assuming an approximately constant $\mathrm{N}$ availability in nearshore settings, this excess phosphorus could not be metabolized and was transported in large quantities over the shelf into distal settings without being consumed, leading to low N/P conditions, compared to the Redfield ratio of $16: 1$. Imbalanced, high phosphorus and low nitrogen availability in distal shelf and open oceanic settings triggered bacterial nitrogen fixation. Thus, the introduction of bioavailable nitrogen species into the open oceanic N-limited settings fueled bioproductivity, leading finally to BS deposition Thus, in our biogeochemical model, the application of the term "highly imbalanced nutrients" or "settings with low N/P ratios" in relation to the Redfield ratio characterizes the system better as eutrophic or oligotrophic.

As shown in Fig. 4, there is a good correlation between $\delta^{15} \mathrm{~N}$ and TOC, independent of whether the sample were deposited during OAE-2 or afterwards. This is clear evidence that BS were formed in a setting with imbalanced nutrients (low N/P ratios) and high nitrogen fixation activity (Sachs and Repeta, 1999). The correlation of 2-methyl anhydroBHTs with decreasing $\delta^{15} \mathrm{~N}$ strongly suggests the occurrence of cyanobacteria capable of nitrogen fixation. This has been also suggested for other OAE 2 settings (Kuypers et al., 2002, 2004; Ohkouchi et al., 2006). Likewise, dinosterol and its derivates indicate that dinoflagellates also bloomed on imbalanced nutrients. Subsequent release of nutrients from the remineralization of this OM most likely triggered growth of other primary producers (indicated by high abundances of algal-derived biomacromolecules), which is supportive of a currently presented model (Higgins et al., 2012). In the opening North Atlantic, similar to the Wunstorf setting, productivity-induced BS formation was reported (Kuypers et al., 2002), and the occurrence of isorenieratane indicates at least temporary photic zone euxina (Pancost et al., 2004; Sinninghe Damsté and Köster, 1998; Fig. 11). In Wunstorf, biomarkers specific to green sulfur bacteria (Summons and Powell, 1986) were not found (isorenieratene or other carotenoids; as well as degradation products). Thus there is no evidence of photic zone euxinia/anoxia in Wunstorf. Instead, foraminiferal (Friedrich et al., 2011) and ichnological (Hilbrecht and Dahmer, 1994) data indicate a fluctuating position of the oxycline between a shallow redox potential discontinuity layer (in the sediment) and the lower part of the water column. In the latter case, the occurrence of the oxycline within the water body results in stratification. A stratified water column then acts as an additional boost for increased growth of bacterial nitrogen fixers compensating losses from microbial denitrification (Deutsch et al., 2007) and/or anaerobic ammonium oxidation (anammox) in anoxic waters. Such a situation is indicated, since tetrahymanone, a biomarker for ciliates grazing at oxic-anoxic interfaces (Sinninghe Damsté et al., 1995; Ten Haven et al., 1989; Thiel et al., 1997), and 2-methyl hopanoids from cyanobacteria show similar correlations against $\delta^{15} \mathrm{~N}$ (Fig. 8a, d). Moreover, considering 3-methyl anhydroBHTs as indicative for methanotrophs or methylotrophs, the high abundances in BS further support a stratified water body with high $\mathrm{C} 1$ substrate turnover. Irrespective of oxygen deficiency close to the sea floor, the upper water column was well-oxygenated as demonstrated by well-developed oceanic food webs represented by, e.g. fish and ammonites (Breitkreutz et al., 1991).

If we assume that phosphorus run-off fueled the BS genesis, then we also need to consider a less imbalanced N/P ratio (compared to Redfield ratio) during the deposition of the white nannofossil-rich limestones intercalated between the BS intervals. Clearly, the alternation of black and white 
beds is an expression of orbital control (Voigt et al., 2008b), and this is also suggested for the concomitant Bonarelli Level in Italy (Mitchell et al., 2008). If we consider maximum BS development and photic zone euxinia during warm phases of the OAE 2 and its absence during cooling stages (e.g., Plenus Event; van Bentum et al., 2012), a scenario as in Fig. 11 is likely, showing a lowering of phosphorus supply during cool stages due to (i) less continental run-off; (ii) less pronounced anoxia; and (iii) a deepening of the oxic-anoxic transition zone in the Central North Atlantic. The persistence of an at least periodically stratified water body (seasonal thermocline?) is also suggested by the occurrence of ciliate biomarkers.

Our data cannot answer the question whether or not bioproductivity was additionally stimulated by submarine volcanic exhalation and $\mathrm{Fe}^{2+}$ release into the sea water. However, it needs to be emphasized that our data can be read as support of the scenario of an "ammonia ocean" (Higgins et al., 2012), since algae and bacteria were both important primary producers during BS formation in Wunstorf. But, BS deposition was related to a source of ${ }^{15} \mathrm{~N}$-depleted biomass (directly or indirectly from nitrogen fixation) and an increasing relative abundance of hopanoid-producing cyanobacteria also in Wunstorf. Nevertheless, our model has the large advantage that biogeochemical loops can elegantly be implemented in geochemical modeling of the OAE 2 as presented by Flögel et al. (2011). Therefore, the complex model of Linnert et al. (2010), who applies various ocean mixing intensities, fertile seasons during BS development and oligotrophic seasons during deposition of calcareous nannofossil ooze, is not required. Furthermore, our model shows the impracticability when thinking about high bioproductivity exclusively in terms of eutrophication (e.g., Hadras and Mutterlose, 2007), as this concept neglects the complex microbial loops potentially associated with BS genesis during the OAE 2.

\section{Conclusions}

Biogeochemical data of a sedimentary succession of BS and calcareous nannofossil ooze deposited in a shelf setting of the OAE 2 suggest that BS formation was induced by enhanced inputs of imbalanced nutrients due to high weathering rates and continental run-off triggered by a $p \mathrm{CO}_{2}$, resulting from the CLIP eruptions. High abundances of 2-methyl and desmethyl hopanoids (anhydroBHTs) suggest that from the resulting low N/P ratios nitrogen fixing cyanobacteria profited, accompanied by (heterotrophic?) dinoflagellates. Accompanying water column stratification during BS deposition is indicated by high abundances of biomarkers from ciliates (tetrahymanone). Biomacromolecules were found to make up the majority of organic matter in the BS, and the composition suggests (among significant allochthonous sources) dinoflagellates and other marine algae as the main origin. Together this supports a - perhaps in the OAE 2 widespread - situation where remineralized cyanobacterial OM boosted the growth of eukaryotic primary producers. This situation and other features are excellently mirrored in depositions of the Wunstorf setting, where the rapid alternations of black shales and limestones allow detailed studies of controls and consequences of biogeochemical changes during the OAE 2.

Acknowledgements. C. Conradt and M. Reinhardt (both University of Göttingen) are kindly acknowledged for laboratory assistance and V. Thiel for sharing ideas. We thank N. Ohkouchi and one anonymous reviewer and $\mathrm{M}$. Weinkauf for their constructive comments. We thank J. Dyckmans (Centre for Stable Isotope Research and Analysis, University of Göttingen) for help with stable nitrogen and compound-specific carbon isotope analysis. $\mathrm{S}$. Voigt is thanked for the stable carbon isotope carbonate data. We thank J. Erbacher (Hannover) for access to the core material, and A. Wülbers (Bremen) for sampling support. We are also indebted to W. Meredith, G. Love and M. Rohrrssen who helped with the installation of the HyPy system in Göttingen. The study was supported by the Deutsche Forschungsgemeinschaft (DFG) through grant BL 971/1-3 and through the Courant Research Center (CRC) Geobiology. The CRC and the University of Göttingen are thanked for the financing of the system for catalytic hydropyrolysis.

This Open Access Publication is funded by the University of Göttingen.

Edited by: N. Ohkouchi

\section{References}

Arouri, K. R., Greenwood, P. F., and Walter, M. R.: Biological affinities of Neoproterozoic acritarchs from Australia: microscopic and chemical characterisation, Organic Geochemistry, 31, 75-89, 2000.

Arthur, M. A., Dean, W. E., and Pratt, L. M.: Geochemical and climatic effects of increased marine organic carbon burial at the Cenomanian/Turonian boundary, Nature, 335, 714-717, 1988.

Barakat, A. O. and Yen, T. F.: Distribution of pentacyclic triterpenoids in Green River oil shale kerogen, Organic Geochemistry, 15, 299-311, 1990.

Bednarczyk, A., Carillo Hernandez, T., Schaeffer, P., Adam, P., Talbot, H. M., Farrimond, P., Riboulleau, A., Largeau, C., Derenne, S., Rohmer, M., and Albrecht, P.: 32,35Anhydrobacteriohopanetetrol: an unusual bacteriohopanepolyol widespread in recent and past environments, Organic Geochemistry, 36, 673-677, 2005.

Berkaloff, C., Casadevall, E., Largeau, C., Metzger, P., Peracca, S., and Viret, J.: The resistant walls of the hydrocarbon-rich alga Botryococcus braunii, Phytochemistry, 22, 389-397, 1983.

Berner, R. A.: Sedimentary pyrite formation: An update, Geochimica et Cosmochimica Acta, 48, 605-615, 1984.

Bisseret, P., Zundel, M., and Rohmer, M.: Prokaryotic triterpenoids. 2. 2b-methylhopanoids from Methylobacterium organophilum 
and Nostoc muscorum, a new series of prokaryotic triterpenoids, European Journal of Biochemistry, 150, 29-34, 1985.

Blumenberg, M., Seifert, R., Kasten, S., Bahlmann, E., and Michaelis, W.: Euphotic zone bacterioplankton sources major sedimentary bacteriohopanepolyols in the Holocene Black Sea, Geochim. Cosmochim. Ac., 73, 750-766, 2009.

Blumenberg, M., Mollenhauer, G., Zabel, M., Reimer, A., and Thiel, V.: Decoupling of bio- and geohopanoids in sediments of the Benguela Upwelling System (BUS), Organic Geochemistry, 41, 1119-1129, 2010.

Blumenberg, M., Thiel, V., Riegel, W., Kah, L. C., and Reitner, J.: Biomarkers of black shales formed by microbial mats, Late Mesoproterozoic (1.1 Ga) Taoudeni Basin, Mauritania, Precambrian Research, 196-197, 113-127, doi:10.1016/j.precamres.2011.11.010, 2012.

Bravo, J.-M., Perzl, M., Härtner, T., Kannenberg, E. L., and Rohmer, M.: Novel methylated triterpenoids of the gammacerane series from the nitrogen-fixing bacterium Bradyrhizobium japonicum USDA 110, European Journal of Biochemistry, 268, 1323-1331, 2001.

Breitkreutz, H., Diedrich, R., and Metzdorf, R.: Fossilfunde aus der Schwarz-Bunten Wechselfolge (Ob. Cenoman bis Unt. Turon) des Ostwestfalendammes bei Bielefeld, Bericht des Naturwissenschaftlichen Vereins von Bielefeld und Umgebung, 32, 3748, 1991.

Derenne, S., Le Berre, F., Largeau, C., Hatcher, P., Connan, J., and Raynaud, J. F.: Formation of ultralaminae in marine kerogens via selective preservation of thin resistant outer walls of microalgae, Organic Geochemistry, 19, 345-350, 1992.

Derenne, S., Largeau, C., and Berkaloff, C.: First example of an algaenan yielding an aromatic-rich pyrolysate. Possible geochemical implications on marine kerogen formation, Organic Geochemistry, 24, 617-627, 1996.

Deutsch, C., Sarmiento, J. L., Sigman, D. M., Gruber, N., and Dunne, J. P.: Spatial coupling of nitrogen inputs and losses in the ocean, Nature, 445, 163-167, 2007.

Duarte, C. M. and Agustí, S.: Rapid carbon cycling in the oligotrophic ocean, Biogeosciences Discuss., 8, 11661-11687, doi:10.5194/bgd-8-11661-2011, 2011.

Erbacher, J., Mutterlose, J., Wilmsen, M., Wonik, T., and Party, W. D. S.: The Wunstorf Drilling Projetc: Coring a global stratigraphic reference section of the Oceanic Anoxic Event 2, Scientific Drilling, 4, 19-21, 2007.

Farrimond, P., Head, I. M., and Innes, H. E.: Environmental influence on the biohopanoid composition of recent sediments, Geochim. Cosmochim. Ac., 64, 2985-2992, 2000.

Flögel, S., Wallmann, K., Poulsen, C. J., Zhou, J., Oschlies, A., Voigt, S., and Kuhnt, W.: Simulating the biogeochemical effects of volcanic $\mathrm{CO}_{2}$ degassing on the oxygen-state of the deep ocean during the Cenomanian/Turonian Anoxic Event (OAE2), Earth Planet. Sci. Lett., 305, 371-384, doi:10.1016/j.eps1.2011.03.018, 2011.

Forster, A., Schouten, S., Moriya, K., Wilson, P. A., and Sinninghe Damsté, J. S.: Tropical warming and intermittent cooling during the Cenomanian/Turonian oceanic anoxic event 2: Sea surface temperature records from the equatorial Atlantic, Paleoceanography, 22, PA1219, doi:10.1029/2006pa001349, 2007.

Freeman, K. H. and Hayes, J. M.: Fractionation of carbon isotopes by phytoplankton and estimates of ancient $\mathrm{CO}_{2}$ levels, Global
Biogeochem. Cycles, 6, 185-198, 1992.

Friedrich, O., Voigt, S., Kuhnt, T., and Koch, M. C.: Repeated bottom-water oxygenation during OAE 2: timing and duration of short-lived benthic foraminiferal repopulation events (Wunstorf, northern Germany), J. Micropalaeontology, 30, 119-128, doi:10.1144/0262-821x11-011, 2011.

Gale, A. S., Smith, A. B., Monks, N. E. A., Young, J. A., Howard, A., Wray, D. S., and Huggett, J. M.: Marine biodiversity through the Late Cenomanian-Early Turonian: palaeoceanographic controls and sequence stratigraphic biases, J. Geol. Soc., 157, 745757, 2000.

Greenwood, P. F., Arouri, K. R., and George, S. C.: Tricyclic terpenoid composition of Tasmanites kerogen as determined by pyrolysis GC-MS, Geochim. Cosmochim. Ac., 64, 1249-1263, 2000.

Hadras, P. and Mutterlose, J.: Calcareous nannofossil assemblages of Oceanic Anoxic Event 2 in the equatorial Atlantic: Evidence of an eutrophication event, Marine Micropaleontology, 66, 5269, 2007.

Hedges, J. I.: Global biogeochemical cycles: progress and problems, Marine Chem., 39, 67-93, 1992.

Hetzel, A., März, C., Vogt, C., and Brumsack, H.-J.: Geochemical environment of Cenomanian - Turonian black shale deposition at Wunstorf (northern Germany), Cretaceous Res., 32, 480-494, doi:10.1016/j.cretres.2011.03.004, 2011.

Higgins, M. B., Robinson, R. S., Husson, J. M., Carter, S. J., and Pearson, A.: Dominant eukaryotic export production during ocean anoxic events reflects the importance of recycled $\mathrm{NH}_{4}^{+}$, Proc. Natl. Acad. Sci., 109, 2269-2274, doi:10.1073/pnas.1104313109, 2012.

Hilbrecht, H. and Dahmer, D. D.: Sediment dynamics during the Cenomanian-Turonian (Cretaceous) Oceanic Anoxic Event in Northwestern Germany, Facies, 30, 63-84, 1994.

Hiss, M., Kaplan, U., and Wiese, F.: Hesseltal-Formation, in: Lithostratigraphie der norddeutschen Oberkreide, edited by: Niebuhr, B., Hiss, M., Kaplan, U., Tröger, K.-A., Voigt, S., Wiese, F., and Wilmsen, M., Schriftenreihe der Deutschen Gesellschaft für Geologische Wissenschaften, 37-38, 2007.

Jahnke, L. L., Summons, R. E., Hope, J. M., and Des Marais, D. J.: Carbon isotopic fractionation in lipids from methanotrophic bacteria II: The effects of physiology and environmental parameters on the biosynthesis and isotopic signatures of biomarkers, Geochim. Cosmochim. Ac., 63, 79-93, 1999.

Jarvis, I., Lignum, J. S., Gröcke, D. R., Jenkyns, H. C., and Pearce, M. A.: Black shale deposition, atmospheric $\mathrm{CO}_{2}$ drawdown, and cooling during the Cenomanian-Turonian Oceanic Anoxic Event, Paleoceanography, 26, PA3201, doi:10.1029/2010pa002081, 2011.

Jenkyns, H. C.: Geochemistry of oceanic anoxic events, Geochemistry Geophysics Geosystems, 11, Q03004, doi:10.1029/2009gc002788, 2010.

Kashiyama, Y., Ogawa, N. O., Kuroda, J., Shiro, M., Nomoto, S., Tada, R., Kitazato, H., and Ohkouchi, N.: Diazotrophic cyanobacteria as the major photoautotrophs during midCretaceous oceanic anoxic events: Nitrogen and carbon isotopic evidence from sedimentary porphyrin, Organic Geochemistry, 39, 532-549, 2008.

Killops, S. and Killops, V.: Introduction to organic geochemistry, 2nd edition, Blackwell publishing, Oxford, 2005. 
Kleemann, G., Poralla, K., Englert, G., Kjøsen, H., Liaaen-Jensen, S., Neunlist, S., and Rohmer, M.: Tetrahymanol from the phototrophic bacterium Rhodopseudomonas palustris: First report of a gammacerane triterpene from a prokaryote, J. General Microbiology, 136, 2551-2553, 1990.

Kokinos, J. P., Eglinton, T. I., Goni, M. A., Boon, J. J., Martoglio, P. A., and Anderson, D. M.: Characterisation of a highly resistant biomacromolecular material in the cell wall of a marine dinoflagellate resting cyst, Organic Geochemistry, 28, 265-288, 1998.

Kriwet, J. and Gloy, U.: Zwei mesopelagische Raubfische (Actinopterygii: Euteleostei) aus dem Unterturon der KronsbergMulde bei Hannover/Misburg (NW Deutschland), Berliner Geowissenschaftliche Abhandlungen, E, 16, 335-356, 1995.

Kuypers, M. M. M., Pancost, R. D., Nijenhuis, I. A., and Sinninghe Damsté, J. S.: Enhanced productivity led to increased organic carbon burial in the euxinic North Atlantic basin during the late Cenomanian oceanic anoxic event, Paleoceanography, 17, 13 pp., 2002

Kuypers, M. M. M., van Breugel, Y., Schouten, S., Erba, E., and Sinninghe Damsté, J. S.: $\mathrm{N}_{2}$-fixing cyanobacteria supplied nutrient $\mathrm{N}$ for Cretaceous oceanic anoxic events, Geology, 32, 853856,2004

Lehmann, M. F., Bernasconi, S. M., Barbieri, A., and McKenzie, J. A.: Preservation of organic matter and alteration of its carbon and nitrogen isotope composition during simulated and in situ early sedimentary diagenesis, Geochim. Cosmochim. Ac., 66, 35733584, 2002.

Linnert, C., Mutterlose, J., and Erbacher, J.: Calcareous nannofossils of the Cenomanian/Turonian boundary interval from the Boreal Realm (Wunstorf, northwest Germany), Marine Micropaleontology, 74, 38-58, doi:10.1016/j.marmicro.2009.12.002, 2010.

Love, G. D., Snape, C. E., Carr, A. D., and Houghton, R. C.: Release of covalently-bound alkane biomarkers in high yields from kerogen via catalytic hydropyrolysis, Organic Geochemistry, 23, 981-986, 1995.

Love, G. D., Snape, C. E., and Fallick, A. E.: Differences in the mode of incorporation and biogenecity of the principal aliphatic constituents of a Type I oil shale, Organic Geochemistry, 28, 797-811, 1998.

Marshall, K. L. and Batten, D. J.: Dinoflagellate cyst associations in Cenomanian-Turonian "Black Shale" sequences of northern Europe, Review of Palaeobotany and Palynology, 54, 85-103, 1988.

Marshall, C. P., Javaux, E. J., Knoll, A. H., and Walter, M. R.: Combined micro-Fourier transform infrared (FTIR) spectroscopy and micro-Raman spectroscopy of Proterozoic acritarchs: A new approach to Palaeobiology, Precambrian Research, 138, 208-224, 2005.

Mitchell, R. N., Bice, D. M., Montanari, A., Cleaveland, L. C., Christianson, K. T., Coccioni, R., and Hinnov, L. A.: Oceanic anoxic cycles? Orbital prelude to the Bonarelli Level (OAE 2), Earth Planet. Sci. Lett., 267, 1-16, 2008.

Morse, J. W. and Emeis, K. C.: Controls on C/S ratios in hemipelagic upwelling regimes, American Journal of Science, 290, 1117-1135, 1990.

Mort, H. P., Adatte, T., Föllmi, K. B., Keller, G., Steinmann, P., Matera, V., Berner, Z., and Stüben, D.: Phosphorus and the roles of productivity and nutrient recycling during oceanic anoxic event 2, Geology, 35, 483, doi:10.1130/g23475a.1, 2007.
Ohkouchi, N., Kuroda, J., Okada, M., and Tokuyama, H.: Why Cretaceous black shales have high $\mathrm{C} / \mathrm{N}$ ratios: Implications from SEM-EDX observations for Livello Bonarelli black shales at the Cenomanian-Turonian boundary, Frontier Research on Earth Evolution, 1, 239-241, 2003.

Ohkouchi, N., Kashiyama, Y., Kuroda, J., Ogawa, N O., and Kitazato, H.: The importance of diazotrophic cyanobacteria as primary producers during Cretaceous Oceanic Anoxic Event 2, Biogeosciences, 3, 467-478, doi:10.5194/bg-3-467-2006, 2006.

Pancost, R. D., Crawford, N., Magness, S., Turner, A., Jenkyns, H. C., and Maxwell, J. R.: Further evidence for the development of photic-zone euxinic conditions during Mesozoic oceanic anoxic events, J. Geol. Soc., London, 161, 353-364, 2004.

Prauss, M.: The Cenomanian/Turonian Boundary Event (CTBE) at Wunstorf, north-west Germany, as reflected by marine palynology, Cretaceous Research, 27, 872-886, doi:10.1016/j.cretres.2006.04.004, 2006.

Rashby, S. E., Sessions, A. L., Summons, R. E., and Newman, D. K.: Biosynthesis of 2-methylbacteriohopanepolyols by an anoxygenic phototroph, Proc. Natl. Acad. Sci., 104, 15099-15104, doi:10.1073/pnas.0704912104, 2007.

Renoux, J. M. and Rohmer, M.: Prokaryotic triterpenoids: New bacteriohopanetetrol cyclitol ethers from the methylotrophic bacterium Methylobacterium organophilum, European Journal of Biochemistry, 151, 405-410, 1985.

Rohmer, M., Bouvier-Navé, P., and Ourisson, G.: Distribution of hopanoid triterpenes in prokaryotes, J. General Microbiology, 130, 1137-1150, 1984.

Sachs, J. P. and Repeta, D. J.: Oligotrophy and Nitrogen Fixation During Eastern Mediterranean Sapropel Events, Science, 286, 2485-2488, doi:10.1126/science.286.5449.2485, 1999.

Salmon, V., Derenne, S., Lallier-Vergès, E., Largeau, C., and Beaudoin, B.: Protection of organic matter by mineral matrix in a Cenomanian black shale, Organic Geochemistry, 31, 463-474, 2000.

Schaeffer, P., Schmitt, G., Adam, P., and Rohmer, M.: Acidcatalyzed formation of 32,35-anhydrobacteriohopanetetrol from bacteriohopanetetrol, Organic Geochemistry, 39, 1479-1482, 2008.

Schaeffer, P., Schmitt, G., Adam, P., and Rohmer, M.: Abiotic formation of 32,35-anhydrobacteriohopanetetrol: A geomimetic approach, Organic Geochemistry, 41, 1005-1008, doi:10.1016/j.orggeochem.2010.04.013, 2010.

Schlanger, S. O. and Jenkyns, H. C.: Cretaceous oceanic anoxic events: causes and consequences, Geologie en Mijnbouw, 55, 179-184, 1976.

Sinninghe Damsté, J. S. and Köster, J.: A euxinic southern North Atlantic Ocean during the Cenomanian/Turonian oceanic anoxic event, Earth Planet. Sci. Lett., 158, 165-173, 1998.

Sinninghe Damsté, J. S., Kenig, F., Koopmans, M. P., Köster, J., Schouten, S., Hayes, J. M., and de Leeuw, J.: Evidence for gammacerane as an indicator of water column stratification, Geochim. Cosmochim. Ac., 59, 1895-1900, 1995.

Sinninghe Damsté, J. S., van Bentum, E. C., Reichart, G.-J., Pross, J., and Schouten, S.: A $\mathrm{CO}_{2}$ decrease-driven cooling and increased latitudinal temperature gradient during the midCretaceous Oceanic Anoxic Event 2, Earth Planet. Sci. Lett., 293, 97-103, doi:10.1016/j.eps1.2010.02.027, 2010. 
Sinton, C. W. and Duncan, R. A.: Potential links between ocean plateau volcanism and global ocean anoxia at the CenomanianTuronian boundary, Economic Geology, 92, 836-842, 1997.

Snape, C. E., Bolton, C., Dosch, R. G., and Stephens, H. P.: High Liquid Yields from Bituminous Coal via Hydropyrolysis with Dispersed Catalysts, Energy \& Fuels, 3, 421-425, 1989.

Summons, R. E. and Powell, T. G.: Chlorobiaceae in palaeozoic seas revealed by biological markers, isotopes and geology, Nature, 319, 763-765, 1986.

Summons, R. E., Volkman, J. K., and Boreham, C. J.: Dinosterane and other steroidal hydrocarbons of dinoflagellate origin in sediments and petroleum, Geochim. Cosmochim. Ac., 51, 30753082, 1987.

Summons, R. E., Jahnke, L. L., Hope, J. M., and Logan, G. A.: 2-Methylhopanoids as biomarkers for cyanobacterial oxygenic photosynthesis, Nature, 400, 554-557, 1999.

Talbot, H. M., Farrimond, P., Schaeffer, P., and Pancost, R. D.: Bacteriohopanepolyols in hydrothermal vent biogenic silicates, Organic Geochemistry, 36, 663-672, 2005.

Talbot, H. M., Summons, R. E., Jahnke, L. L., Cockell, C. S., Rohmer, M., and Farrimond, P.: Cyanobacterial bacteriohopanepolyol signatures from cultures and natural environmental settings, Organic Geochemistry, 39, 232-263, 2008.

Ten Haven, H. L., Rohmer, M., Rullkoetter, J., and Bisseret, P.: Tetrahymanol, the most likely precursor of gammacerane, occurs ubiquitously in marine sediments, Geochim. Cosmochim. Ac., 53, 3073-3079, 1989.

Thiel, V., Jenisch, A., Landmann, G., Reimer, A., and Michaelis, W.: Unusual distributions of long-chain alkenones and tetrahymanol from the highly alkaline Lake Van, Turkey, Geochim. Cosmochim. Ac., 61, 2053-2064, 1997.

Tsikos, H., Jenkyns, H. C., Walsworth-Bell, B., Petrizzo, M. R., Forster, A., Kolonic, S., Erba, E., Premoli Silva, I., Baas, M., Wagner, T., and Sinninghe Damsté, J. S.: Carbon-isotope stratigraphy recorded by the Cenomanian-Turonian Oceanic Anoxic Event: correlation and implications based on three key localities, J. Geol. Soc., 161, 711-719, doi:10.1144/0016-764903-077, 2004.

Turgeon, S. C. and Creaser, R. A.: Cretaceous oceanic anoxic event 2 triggered by a massive magmatic episode, Nature, 454, 323326, 2008

Ulicný, D., Hladíková, J., Attrep, M. J., Cech, S., Hradecká, L., and Svobodá, M.: Sea-level changes and geochemical anomalies across the Cenomanian-Turonian boundary: Pecinov quarry, Bohemia, Palaeogeography, Palaeoclimatology, Palaeoecology, 132, 265-285, 1997.

van Bentum, E. C., Reichart, G.-J., Forster, A., and Sinninghe Damsté, J. S.: Latitudinal differences in the amplitude of the OAE-2 carbon isotopic excursion: $p \mathrm{CO}_{2}$ and paleo productivity, Biogeosciences, 9, 717-731, doi:10.5194/bg-9-717-2012, 2012.

van de Meent, D., Brown, S. C., Philp, R. P., and Simoneit, B. R. T.: Pyrolysis-high resolution gas chromatography and pyrolysis gas chromatography-mass spectrometry of kerogens and kerogen precursors, Geochim. Cosmochim. Ac., 44, 999-1013, 1980.
Versteegh, G. J. M., Blokker, P., Bogus, K. A., Harding, I. C., Lewis, J., Oltmanns, S., Rochon, A., and Zonneveld, K. A. F.: Infra red spectroscopy, flash pyrolysis, thermally assisted hydrolysis and methylation (THM) in the presence of tetramethylammonium hydroxide (TMAH) of cultured and sediment-derived Lingulodinium polyedrum (Dinoflagellata) cyst walls, Organic Geochemistry, 43, 92-102, doi:10.1016/j.orggeochem.2011.10.007, 2012.

Voigt, S., Gale, A. S., and Flögel, S.: Midlatitude shelf seas in the Cenomanian-Turonian greenhouse world: Temperature evolution and North Atlantic circulation., Paleoceanography, 19, PA4020, doi:10.1029/2004PA001015, 2004.

Voigt, S., Aurag, A., Leis, F., and Kaplan, U.: Late Cenomanian to Middle Turonian high-resolution carbon isotope stratigraphy: New data from the Münsterland Cretaceous Basin, Germany, Earth Planet. Sci. Lett., 196-210, 2006 a.

Voigt, S., Gale, A. S., and Voigt, T.: Sea-level change, carbon cycling and palaeoclimate during the Late Cenomanian of northwest Europe; an integrated palaeoenvironmental analysis, Cretaceous Research, 27, 836-858, doi:10.1016/j.cretres.2006.04.005, 2006b.

Voigt, S., Erbacher, J., Mutterlose, J., Weiss, W., Westerhold, T., Wiese, F., Wilmsen, M., and Wonik, T.: The Cenomanian Turonian of the Wunstorf section - (North Germany): global stratigraphic reference section and new orbital time scale for Oceanic Anoxic Event 2, Newsletters on Stratigraphy, 43, 6589, doi:10.1127/0078-0421/2008/0043-0065, 2008a.

Voigt, S., Erbacher, J., Mutterlose, J., Weiss, W., Westerhold, T., Wiese, F., Wilmsen, M., and Wonik, T.: The CenomanianTuronian of the Wunstorf section - (North Germany): global stratigraphic reference section and new orbital time scale for Oceanic Anoxic Event 2, Newsletters on Stratigraphy, 43, 6589, 2008b.

Westermann, S., Caron, M., Fiet, N., Fleitmann, D., Matera, V., Adatte, T., and Föllmi, K. B.: Evidence for oxic conditions during oceanic anoxic event 2 in the northern Tethyan pelagic realm, Cretaceous Research, 31, 500-514, 2010.

Wiese, F.: The Söhlde Formation (Cenomanian, Turonian) of NW Germany: Shallow marine red beds, in: Cretaceous Oceanic Red Beds: Stratigraphy, Composition, Origins, and Paleoceanographic and Paleoclimatic Significance, edited by: Scott, R. W. Jansa, L., Wang, C., Hu, X., and Wagreich, M., SEPM Special Publications, 153-170, 2009.

Wilmsen, M., Niebuhr, B., and Hiss, M.: The Cenomanian of northern Germany: facies analysis of a transgressive biosedimentary system, Facies, 51, 242-263, 2005.

Wood, C. J. and Ernst, G.: C 2.4 Cenomanian-Turonian of Wunstorf, in: Bochumer Geologische und Geotechnische Arbeiten, edited by: Mutterlose, J., Bornemann, A., Rauer, S., Spaeth, C., and Wood, C. J., Key localities of the northwest European Cretaceous, Institut für Geologie und Paläontologie, Bochum, 62-73, 1998.

Zundel, M. and Rohmer, M.,: Prokaryotic triterpenoids. 3. The biosynthesis of $2 \beta$-methylhopanoids and $3 \beta$-methylhopanoids of Methylobacterium organophilum and Acetobacter pasteurianus ssp. pasteurianus, European Journal of Biochemistry, 150, 3539, 1985. 